\title{
Principles involved in assessing energy, protein and micronutrient needs during infancy
}

By R. G. Whitehead, Dunn Nutrition Laboratory, Milton Road, Cambridge $\mathrm{CB}_{4} \mathrm{IXY}$ and Keneba, The Gambia

Our knowledge of nutrient requirements during infancy is nothing like as secure as many nutritionists would like to believe. In the present paper I will summarize the estimates contained in the latest Food and Agriculture Organization/World Health Organization/United Nations University (FAO/WHO/UNU) (1985) report on energy and protein requirements, indicate recent research findings relevant to the report and also identify major gaps in our knowledge.

\section{Basic concepts used by $F A O / W H O / U N U$ (1985) in the formulation of their recommendations}

Understandably perhaps, a primary yardstick for our current estimates of energy and nutrient needs is what the $0-3$-month-old healthy child receives during the course of breast-feeding from a well-nourished mother, who in the early infancy of her child is dedicated to this sole mode of feeding. This latter proviso is very important because the amount of milk taken by the young baby from the mother at each feed must be dependent on his degree of hunger and clearly this will be modified if other foods have been made available as well as breast milk, however small in amount. Since the fat content of human milk also increases during the course of each feed from both breasts, and the initial fat content is dependent on how much milk was taken at the last feed, the energy content of the milk consumed as well as the total volume, become influenced in a complex manner (Prentice et al. I98I).

Breast-feeding can only be a reliable guide to nutrient needs during the first few months of infancy. The average period for which breast-feeding alone can satisfy the total needs of the child is in fact a matter of considerable controversy but within the present context of nutritional requirements one can assume that up to 3 months should be a safe baseline for any calculations.

The volume of milk consumed by a baby is normally measured by test-weighing. This method, which requires the acccurate weighing of the baby before and after each and every feed can, nevertheless, be remarkably accurate in the hands of experienced investigators who have the collaboration of considerate and helpful mothers. Reported volumes of milk consumed quickly rise to population mean plateaux of between 750 and $850 \mathrm{ml} / \mathrm{d}$ by about $1-2$ months, after which they tend to remain more or less at this level unless the mother introduces supplementary feeding, when values tend to fall again (Prentice et al. 1986).

The consistency of such quantitative information on breast-milk consumption 
formed one of the major tenets of the protein and energy recommendations formulated by the FAO/WHO/UNU (1985) consultative group when they met in Rome in October 1981. For protein it also had to be assumed that human milk contained, on average, $11.5 \mathrm{~g}$ protein/l, an assumption which will be discussed later (p. 364). This formed the basis of the recommendation up to 4 months of age. After this age protein requirements were based on nitrogen balance data. From the $\mathrm{N}$ balances, maintenance requirement values for zero growth and $\mathrm{N}$ equilibrium on milk or egg protein were calculated by regression analysis but small extra increments for sweat and other miscellaneous losses had to be added. Maintenance values at subsequent stages during childhood were determined by linear interpolation between the infancy estimates and that concluded to be appropriate for the average adult from $\mathrm{N}$ balance studies. To all the resultant maintenance protein requirements were added a second series of values, estimated to be the necessary egg- or mill-protein increment needed to support a normal velocity of growth at the various ages. It was also necessary, however, to make further safety margin $(+50 \%)$ allowances and corrections for efficiency of protein utilization during growth $(70 \%)$. The validity of these complex assumptions during later infancy had to be justified by the closeness of fit with the assumed protein intake of a baby if it was breast-fed. This further emphasizes the importance of the information on protein composition and knowledge concerning the average quantity of milk consumed at different ages in early infancy.

In the case of the energy recommendations, the 1981 consultative group (FAO/WHO/UNU, I985), moved away from the time-honoured view held by the 1971 committee (FAO/WHO, 1973) that over the Ist year of life energy needs, expressed on a per $\mathrm{kg}$ body-weight basis, fall only slowly, from $500 \mathrm{~kJ} / \mathrm{kg}$ at o-3 months down to $44^{\circ} \mathrm{kJ} / \mathrm{kg}$ at I year. The 1981 consultative group (FAO/WHO/UNU, I985), after reviewing recent literature on the food intakes of healthy young infants (discussed by Whitehead et al. 1981), decided that food energy needs initially fall more quickly than this and they concluded that by 6 months it would be safe to assume that the average requirement was probably not more than $400 \mathrm{~kJ} / \mathrm{kg}$. After this age the group (FAO/WHO/UNU, 1985) concluded that energy needs might very well rise again in order to accommodate the increased level of activity of children once they start to crawl and then walk. To account for this, the estimated needs were gradually raised again by about $5 \%$ from 6 months to I year.

The resultant metabolizable energy needs and requirements for high-quality protein, such as from milk or egg, are given in Table I. Expressed in this form, the protein recommendations are not too dissimilar between the two reports (FAO/WHO, 1973; FAO/WHO/UNU, 1985) and, although lower at 6 months by I year, the estimated energy needs more or less equate. Such a simple comparison is misleading, however. The 1981 (FAO/WHO/UNU, 1985) group, unlike the 1971 (FAO/WHO, 1973) committee, recommended that, when allowing for protein quality, corrections for both digestibility and amino acid content should be considered. Whilst in the adult a digestibility correction only is usually required, 
Table I. A comparison of the daily energy and protein needs of infants estimated by the Food and Agriculture Organization/World Health Organization (1973) and the Food and Agriculture Organization/World Health Organization/United Nations University (1985)

(Protein recommendations expressed as mill or egg protein; for details, see p. 362)

\begin{tabular}{|c|c|c|c|c|}
\hline \multirow{2}{*}{$\begin{array}{c}\text { Age } \\
\text { (months) }\end{array}$} & \multicolumn{2}{|c|}{ Energy $(\mathrm{kJ} / \mathbf{k g})$} & \multicolumn{2}{|c|}{ Protein $(\mathrm{g} / \mathrm{kg})$} \\
\hline & 1973 & 1985 & 1973 & 1985 \\
\hline $0-3$ & 500 & $4^{85}$ & - & - \\
\hline $3-6$ & $4^{80}$ & 415 & - & 1.86 \\
\hline $6-9$ & 460 & 400 & $1 \cdot 62$ & 1.65 \\
\hline $9-12$ & 440 & 420 & $1 \cdot 44$ & $1.4^{8}$ \\
\hline
\end{tabular}

because of enhanced amino acid requirements relating to growth, an amino acid composition correction is often necessary with protein sources of poorer quality when one is dealing with the preschool child. The effect of this on protein requirements from diets in different parts of the world is shown in Table 2 for children aged $\mathrm{I}-1.5$ years. Those living on typical family diets from Tunisia or India would, according to the latest (FAO/WHO/UNU, 1985) recommendations, need about $20-30 \%$ more protein than would have been judged adequate by the earlier committee (FAO/WHO, 1973).

Factors complicating the estimation of energy and protein needs in infancy

It is quite clear that the conclusion about protein needs is very dependent on the I981 group's (FAO/WHO/UNU, 1985) interpolation procedure for calculating

Table 2. A comparison of the daily protein requirements of young children aged I-I.5 years after correcting typical traditional family diets for protein quality according to the Food and Agriculture Organization/World Health Organization (1973) and for protein quality and digestibility according to the Food and Agriculture Organization/World Health Organization/United Nations University (1985)

\begin{tabular}{|c|c|c|c|c|c|}
\hline \multirow[b]{3}{*}{ Country } & \multicolumn{4}{|c|}{ Protein requirement $(\mathbf{g} / \mathbf{k g})$} & \multirow{3}{*}{$\begin{array}{l}\text { Percentage } \\
\text { change between } \\
\text { reports }\end{array}$} \\
\hline & \multicolumn{2}{|r|}{1973} & \multicolumn{2}{|r|}{1985} & \\
\hline & Egg & Traditional diet & Egg & Traditional diet & \\
\hline Tunisia* & $I \cdot 23$ & 2.05 & $1 \cdot 26$ & 2.60 & +24 \\
\hline Indiat & $I \cdot 23$ & $1 \cdot 76$ & $I \cdot 26$ & $2 \cdot 13$ & +21 \\
\hline United States $\ddagger$ & $I \cdot 23$ & $1 \cdot 54$ & $I \cdot 26$ & $1 \cdot 30$ & -16 \\
\hline
\end{tabular}

-Assumed 1973 protein score 60; 1985 digestibility 85, amino acid score 57.

†Assumed 1973 protein score 70 ; 1985 digestibility 81 , amino acid score 73 .

$\ddagger$ Assumed 1973 protein score $80 ; 1985$ digestibility 100 , amino acid score 97 . 
protein needs for maintenance and the primary importance which was attached to the breast-milk compositional value of $1 \mathrm{I} \cdot 5 \mathrm{~g}$ protein/l. This value was arrived at after large numbers of $\mathrm{N}$ estimations on breast-milk samples from various countries but it used the simple factor of $6 \cdot 25$ to convert $\mathrm{N}$ into protein. Since the I981 meeting ( $\mathrm{FAO} / \mathrm{WHO} / \mathrm{UNU}, \mathrm{I}_{98}$ ) it is becoming increasingly clear, however, that a substantial portion of the $\mathrm{N}$ in milk is not in the form of simple dietary proteins and it is debatable even if all the protein-like compounds are available for anabolic processes (Raiha, 1980; Hambraeus et al. 1984). It has been known for many years that there is a significant amount of urea plus small-molecular-weight nitrogenous compounds in milk but there are also immunoproteins and other 'protective factors' believed to be important for protecting the child against intestinal disorders. If the protective factors are to play their supposed role in the intestine it is obvious, that at least in part, they must avoid digestion and absorption. At the present time we do not know precisely how much of the non-protein- $\mathrm{N}$ and the immunoproteins in breast milk are unavailable for tissue building but it would seem unlikely that the true dietary protein content of breast milk can be as high as $I I \cdot 5 \mathrm{~g} / \mathrm{l}$. If it were only $9 \mathrm{~g} / \mathrm{l}$, for example, and it were accepted, as surely it must, that breast milk contains sufficient protein for healthy growth up to $2-3$ months, then it would have to be concluded that the early infancy baseline used to justify the protein interpolation calculations might have been set at too high a value. If this indeed proves to be true, some of the calculated extra protein apparently necessary (Table 2) for older infants living on typical family diets from the Third World might need to be reconsidered. Quite clearly we need more exact information on the dietary availability of the different nitrogenous compounds in human breast milk if we are to have an adequate understanding of the protein needs of infants and preschool children.

The energy-requirement argument also is very dependent on assumptions about the composition of human milk and this too is an area where we need more information. The value adopted by the $\mathrm{FAO} / \mathrm{WHO} / \mathrm{UNU}$ ( 1985 ), like most other national and international expert committees, was $2900 \mathrm{~kJ}(700 \mathrm{kcal}) / 1$, the value obtained from the analysis of the protein, fat and carbohydrate of expressed breast milk. As already discussed, in the infant actually being breast-fed, the milk consumed within a given feed has a variable energy content. Because the fat content at the beginning of a feed from each breast is low, the initial energy content is also low but rises as the feed proceeds. There has been speculation

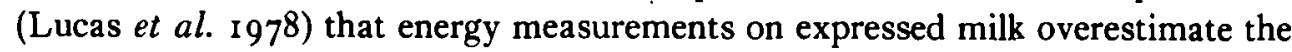
true energy intake obtained during normal lactation, particularly during the initial phases of infancy when breast milk is produced in abundance and the baby rarely has to work for the more energy-rich hind milk.

The application of the new stable isotope approach, using deuterium and ${ }^{18} \mathrm{O}$-labelled water, should greatly enhance our capacity to define energy expenditure, and hence needs, more adequately during infancy and the preschool period. This approach is being adopted by my colleagues, $\mathrm{Dr}$ Alan Lucas and Dr Sue Roberts, in Cambridge. 


\section{Vitamin and mineral needs}

Vitamin and mineral needs during infancy, like those for protein and energy, are based on the amounts customarily found in human milk but, unlike protein and energy, milk composition with respect to many of the other nutrients is very dependent on the dietary intake of the mother. The basis for international estimates is again the nutrient content of the milk from healthy mothers living in the richer, industrialized countries. It is very likely, however, that such mothers are living on diets which contain nutrients at well above minimum physiological requirements. Furthermore, many women may well be taking additional supplementary vitamin preparations during the reproductive phases of their lives, especially in the United States, and thus inevitably they will tend to have substantially more of these nutrients in their milk than a healthy mother living on levels of nutrients not substantially in excess of what she needs. Thus once again using breast-milk composition as the primary basis for estimating infant nutritional needs begs a number of critical scientific questions. Since the subsequent needs of children as they grow older are also derived indirectly from breast-millk compositional values by interpolation, with these age-groups too there is a probable overestimation of physiological needs. Whilst this is not of any great practical significance for populations in the Western world, it is important in terms of health-planning strategies for Third World countries where many of our current recommendations could only be achieved if quite major changes to agricultural practices were introduced. In countries where one has to rank developmental priorities with great care, better information on the true physiological need for micronutrients would be highly desirable.

\section{Individual variation in needs}

In infants as well as adults there is a fundamental interpretational difference between the estimates we give for energy needs and for the rest of the nutrients. With energy, the tabulated requirement is always for the average infant within the community at a given age. With the other nutrients it is the amount calculated to be necessary to cover the needs of the great majority of infants, the statistical percentage usually covered being the mean plus two standard deviations or about $97 \%$ of the population. There are a number of reasons for this difference in approach. First there is a natural hunger for energy but it is very debatable whether this exists for many of the nutrients. Thus it is assumed that if one makes available, to a large enough group, sufficient to cover average energy needs then each individual will, in the long term, be able to eat to cover his needs. Clearly with the other nutrients, in the absence of any intake-controlling mechanism, such an assumption would not be valid. Furthermore, with the other nutrients there is no physiological harm if the majority of individuals do overconsume, within the range set by the theoretical calculations, but with energy the same assumption could not be made if the risk of encouraging infantile obesity were to be avoided.

What is not widely appreciated, however, is how great the variation in energy 
and nutrient needs probably is. This is readily apparent from an examination of the regular breast-milk intakes of different children. In studies carried out among healthily growing, 2-month-old babies in Cambridge, for example, the range of milk intakes covered well over a twofold range, from 445 to $1235 \mathrm{ml} / \mathrm{d}$ (Whitehead \& Paul, 1981). Part of the variance could be accounted for by differences in the weight of the babies and on their velocities of growth, but by no means all, thus raising the possibility of there being additional variations in the ability of individual babies to assimilate energy and nutrients for anabolic purposes. Be this as it may it does illustrate the care that nutritionists must take in using recommended allowances to interpret either the needs or intakes of small groups and especially individuals. A common question asked of the health professions both in the UK and overseas is 'how long can breast-feeding alone be adequate to cover all the nutritional needs of the baby and, consequently, when does complementary feeding become necessary?' There is a popular vogue for giving a single age but this is obviously irrational; there must be a range of ages. The usual range quoted in the UK is $3^{-6}$ months but such advice is obviously only very general and it would seem sensible for a mother to be encouraged to follow her natural instincts in so far as her own baby is concerned. Perhaps because baby boys tend to be larger than baby girls and they also grow faster, complementary feeding does tend to be introduced rather earlier in boys but one can never rule out the possibility that 'folk beliefs' about the extra nutritional needs of a boy in contrast to a girl influence a mother even at this very early stage (Whitehead \& Paul, x98r).

\section{Assessment of the adequacy of infant-feeding practices}

The traditional way of assessing the adequacy of infant-feeding practices is via prospectively-recorded weight measurements with the results for the individual baby being plotted $v$. standard values on a growth chart. This procedure has long been carried out by health workers in the Third World but growth charts are finding increased usage by health workers and also individual mothers in the industrialized world as well. We have, however, pointed out a number of problems with current weight charts in so far as infancy is concerned: the most important is that the major growth standards were compiled from anthropometric measurements made on children who were fed in a way we would now consider less than ideal, that is bottle-fed from the outset, with solid foods, including mashed family food, being introduced at a very early age. The great majority of the children in the internationally-adopted National Center for Health Statistics weight standards (Hamill, 1977) and the British Tanner standards (Tanner et al. 1966) were certainly bottle-fed and probably had solids introduced as early as I month. A number of studies of growth among healthy babies in Europe, America and Australia have indicated that patterns of both weight and height velocities have changed now that breast-feeding is becoming popular again and solids are being commenced later (Whitehead \& Paul, 1984). If growth standards based on inappropriately-fed babies are used to judge current growth performances there is a danger that the onset of diet-induced poor growth might be suspected when it 


\section{Vol. 45 Nutrient recommendations for man-theory and practice 367}

should not be. There is clearly a need for infancy-specific growth charts to be produced for babies being fed on diets compatible with current paediatric advice. Preliminary studies are being carried out by the Dunn Nutrition Unit in Cambridge in an attempt to convince the paediatric community of the importance of such a venture.

\section{REFERENCES}

Food and Agriculture Organization/World Health Organization (1973). Energy and Protein Requirements. Technical Report Series no. 522. Geneva: WHO.

Food and Agriculture Organization/World Health Organization/United Nations University (1985). Energy and Protein Requirements. Technical Report Series no. 724. Geneva: WHO.

Hambraeus, L., Fransson, G.-B. \& Lonnerdal, B. (1984). Lancet ii, 167-168.

Hamill, P. V. V. (1977). NCHS Growth Curves for Children, Birth to I8 years. US Department of Health, Education and Welfare publication no. PHS 78-1650. Hyattsville: National Center for Health Statistics.

Lucas, A., Gibbs, J. A. H. \& Baum, J. D. (1978). Early Human Development 4, 351-361.

Prentice, A., Prentice, A. M. \& Whitehead, R. G. (1981). British Fournal of Nutrition 45, 483-494.

Prentice, A. M., Whitehead, R. G., Prentice, A. \& Cole, T. J. (1986). In Proceedings of XIII International Congress of Nutrition, Brighton, [T. G. Taylor, editor]. London: John Libbey (In the Press).

Raiha, N. C. R. (1980). Advances in Nutritional Research 3, 173-206.

Tanner, J. M., Whitehouse, R. M. \& Takaishi, M. (1966). Archives of Disease in Childhood 4I, $613-635$.

Whitehead, R. G. \& Paul, A. A. (1981). Lancet ii, 16r-163.

Whitehead, R. G. \& Paul, A. A. (1984). Early Human Development 9, 187-207.

Whitehead, R. G., Paul, A. A. \& Cole, T. J. (1981). Foumal of Human Nutrition 35, 339-348. 